\title{
DOI 10.26886/2414-634X.2(46)2021.5
}

UDC 130.2:128.5

\section{THE PROBLEM OF SOCIALITY IN GERMAN CLASSICAL} PHILOSOPHY: BETWEEN FREEDOM AND NECESSITY

\section{O. Yatsenko, Candidate of Philosophical Sciences, Associate Professor}

http://orcid.org/0000-0003-0584-933X

e-mail: yatsenkood@gmail.com

National Pedagogical Dragomanov University Ukraine, Kyiv

The article argues that the contradiction between mathematical necessity and the philosophical concept of freedom becomes a real road stone of idealist philosophy. Based on the inherent German classical philosophy of the absolutization of the subject, extends to the internalization of universal concepts of culture as the social nature of reason and rationality. It is proved the understanding of culture as an explication of activity, which based on ethical and axiological norms, and is consolidated in a single human community. The author argues that in the dialectic of the abstract and the concrete, the essence and the existing beginning of life is completed in the forms of thinking, and this is specifically the human, cultural way of being. That is, the personification of culture in the face of the subject is a process of forming a culture of personal thinking, and universal heritage (historical memory) in the communicative space of society is extrapolated to individual consciousness, which in turn becomes the driving force of the cultural process.

Key words: culture, sociality, freedom, necessity, subjectivity, thinking, transcendental apperception.

кандидат фрілософрських наук, доцент, Яценко О., Проблема соціальності у німецькій класичній фрілософії: між свободою $i$ 
необхідністю / Національний педагогічний університет ім. М. Драгоманова, Україна, Київ

В статті стверджується, що протиріччя між математичною необхідністю та фрілософрським поняттям свободи стає справжнім наріжним каменем ідеалістичної фрілософрії. Виходячи із притаманної німецькій класичній фрілософії абсолютизації суб'єкта, обгрунтовано інтеріоризацію універсальних концептів культури як соціальної природу розуму та раціональності. Доведено розуміння культури як експлікації активності на засадах етико-аксіологічних нормативів, що консолідують в єдність людську спільноту. Автор аргументує, що в діалектиці абстрактного та конкретного, сутності та сущого начала буття знаходять завершення в формах мислення, і в цьому полягає специфрічно людський, культурний спосіб буття. Тобто, персоніфікація культури в особі суб'єкта є процесом формування культури мислення особи, а загальнолюдське надбання (історична пам'ять) в комунікативному просторі сочіуму екстраполюється в індивідуальну свідомість, яка, в свою чергу, стає рушієм культуротворчого процесу.

Ключові слова: культура, соціальність, свобода, необхідність, суб'єктивність, мислення, трансцендентальна апперцепція.

Formulation of the problem. German idealist philosophy has every reason to be considered classical. From the point of view of the content of philosophizing, there are two defining features: the universality of the problem field of research and the systematic nature of the categorical apparatus. This combination leads, in essence, to the logical exhaustion of the tradition of philosophizing, bringing to the limit of the realization of its inherent intentions. This heuristic approach is explained by the contradictory desire to give philosophy as much as possible the likeness of 
science, to create a depleted and refined rational construction of the world, in which all the natural achievements have a reasonable place. Accordingly, it is in the contradiction of necessity and freedom that it is appropriate to analyze the problem of sociality. These theoretical issues, which have a clear and pronounced praxeological dimension, are the main focus of two international projects: Jean Monnet's Department of Social and Cultural Aspects of European Studies (SCAES) and Jean Monnet's EU Values of Diversity and Inclusion for Sustainable Development (EVDISD), which began in 2020 at the NPDU.

Analysis of recent research and publications. The problem of sociality in the dialectic of freedom and necessity, actualized by German classical philosophy, has significant potential for modern worldviews. James D. argues that the concept of absolute good is the ideological basis of the philosophy of the Enlightenment and has a significant impact on the course of worldview analysts of society. Piirimäe E. and Schmidt A. study the influence of the concept of sociability on social, political and international relations, principles of morality and normative behavior of subjects in society. Baghai F. analyzes the problem of freedom and necessity in the theory of the Enlightenment by I. Kant, and substantiates the critical and rational foundations of this phenomenon. Cain $A$. proves that the problem of sociality in Kant's philosophy is solved through the contradiction between a metaphysically grounded spectator and a physically located actor, the specificity of which eliminates the spontaneity and complexity of social interaction. Laitinen $A$. and others consider the problem of freedom and moral law as the main determinants of human activity in the works of I. Kant and F. Hegel. Schafer K. carries out a critical analysis of the expediency of Kant's interpretation of metaethics as a prerequisite for the development of constitutionalist and constructivist approaches in philosophy. Ware O. insists that the realization of the moral law is the metaphysical basis of 
I. Fichte's idealism. Moggach D. argues the organismic solution of social and political problems by F. Schelling and F. Hegel. Redding P. proves the social nature of the human mind on the basis of modal logic and general principles of rationality. Testa I. argues that the inner sociality of man doesn't contradict natural factors and tendencies. Thus, the dialectic of nature and freedom in the definition of sociality is a significant achievement of the German classics.

Presenting main material. The classical metaphysical setting presupposes cognition through the establishment of a cause, to understand the world - means to see its origin with the inner vision. But the emergence of the world is not a one-time affair, but a prolonged process - this is the worldview break since the Renaissance, and therefore needs its own adequate explanation. Of course, knowledge is the fixation of the constant in the flowing, it is impossible under chaotic transformations. And here there is a fundamentally different idea and feeling of space "... the world is located in a straight line of the sun's rays", "... for the infinite, open in the"next "universe Bruno everything takes on a different meaning" [12, p.169]. Therefore, Newton (personification of science, according to Kant) notes the need to study not the state of the world, but its formation; dynamics and patterns of change. The contradiction between mathematical necessity and the philosophical concept of freedom becomes a real cornerstone of idealistic philosophy. Reality as a clear system of connections between determination and thinking (consciousness), as well as a clear system of judgments in the course of reasoning, demonstrate self-sufficiency and autonomy of their existence. The question arises about the nature of their relationship in the plane of freedom. Therefore, the problem of culture as a field of realization of freedom, a field of activity and self-expression becomes extremely important. And, of course, both the notion of freedom and the notion of culture lose their meaning without the 
presence of the Other. The priority of the epistemological setting has its influence on the understanding of nature and on the definition of sociality. Sociality is understood as the awareness of belonging to the general and recognition of the individual. However, the accents are somewhat changed: the concept of the Other is largely internalized and subordinated to the individual subject. Thus, V. Bibler defines the maxims of the worldview of the culture of the Enlightenment: 2) mentally put yourself in the place of each other (think of yourself in communication with people); 3 ) always think in harmony with yourself" [13, p.177]. This dialectical scheme of classical philosophy contains the general principle of human's relationship to the world: the explication of the self through interaction and experience and return to self. The ancient mythological principle of the hero's travels in search of meaning, which finally describes the circle in the tightness of the universe. A new type of sociality strives for tightness in the face of boundless space. Therefore, the problems of sociality are the most thorough solution.

I. Kant creates a legal approach to epistemology, which means a steady trend of revision of the original grounds, and hence - criticism. Indicative in this metaphysical setting should not be called even fundamental openness, but rather teleological orientation, the idea of purpose, or its desire, and presented it in the basis of the concept of the whole. This heuristic procedure can be compared to searching for relevant objects in the world according to the required ideas, or embedded images. I. Kant is categorical in formulating the principles: "... the scientific concept of reason contains the purpose and the corresponding form of the whole" $[14$, p.486]. The very idea of the mind plays a constructive function in relation to reality: "The idea is the concept of the mind about the shape of a certain whole, because it a priori determines the volume of various and the position of parts relative to each other" [114, p.1043]. Kant also calls the 
idea of reason "the scheme of the concept of a thing in general", according to this orientation the systematic unity of empirical experience is dependent on the imagined object of this idea, in which representation is the basis or cause of perception of things. (But: if the mind is blind, or the heart is indifferent). Thus, the concept of one and whole is that which seeks to bring consciousness into the world. Knowledge is a procedure of ordering chaos, and "to be" for a person means purposeful and rational activity to master oneself and the environment. The well-known Kantian slogan of the Enlightenment: "Have the courage to use your own mind!". The realization of this courageous attitude to the world is the realization of freedom in the sense that it allows the subject himself to find objective principles, general and universal principles. Thus, the objective unity of empirical consciousness is based on the primary apperception as a necessary condition of any possible perception that occurs according to a priori established rules. As is well known, Kant was rather skeptical about Cartesian innate ideas. A priori knowledge contains a historical element, convinces in "Kantian variations" M.K. Mamardashvili. Both the forms of contemplation and the categories should be understood more as rules that can be followed - then success is guaranteed, or you can not follow - in this case there are no guarantees of obtaining true knowledge. The imitation of these rules is carried out in education, as in the case of the formation of aesthetic taste, or mastering the terminology of a particular field of knowledge. Transcendental apperception, or cogito, in this perspective acts as a connection of existence, a topology that pulls to the point and holds the acts of conscious life. The fundamental simplicity of the self does not mean its constancy or completeness: "The world, like me, according to Kant, is not pre-defined" [16, p.234]. This situation is a prerequisite for freedom, because it is conceivable only in the presence of necessity or determination. I. Kant calls this principle of a certain communication of 
substances together with the existing internal element "I" a "form of the world." Form is the possibility of structure, organization of completeness of content, or education, the nature of which depends on the worldview as a whole, human life in general. Therefore, reason is not the psychology of an individual, not the field of evaluation or decision. Its significance lies in the universal principle of the integrity of culture. That is, pure reason as an operating system is a product of the existence of culture, space of spirit or intelligentsia, which acts in relation to chaotic empiricism as a factor of formation.

Indeed, categorical thinking, which forms the basis of rationality, is reason to believe that it is contradictory in terms of constancy. The exact analogy of this contradiction is formulated by $\mathrm{V}$. Bibler as incompatibility of series and aggregate. The temporal flow, or relations of determination, are formed on a linear basis. D. Hume's question about the nature of the cause: "does" after "-" because "?", as was awakened I. Kant from a dogmatic dream. But there are not only temporal, but also spatial dependencies of objects, so the world is essentially not a series, but a unit - a mechanism agreed in a certain way. Pure contemplation means analyzing the ideas of space and time, not their sum. Therefore, it is possible to speculatively distinguish these data in the unity of characteristics. "Space is a whole that is not part of any other whole" [14, p.51]. Boundary abstraction, possibility and condition of presence. Time as a sequence underlies the concept of cause: the objective sequence of elements of experience is interpreted as a causal relationship. In contrast to dogmatic metaphysics, in which reason has been interpreted as the "fate of things," inner strength and potency, Kantian metaphysics understands reason as the power of the subject who puts it into experience and carries it out. After all, substances constantly interact: if consistently - this is the cause, if at the same time - this is 
communication, the relationship that arises between the subject and the idea. This relationship is usually called the basis.

In the field of logic, this contradiction is actualized as a diversity of the law of identity and the law of sufficient grounds. Thus, according to the law of identity, thinking is the operation of certain discrete meanings. But in this case the meaning is closed from cognition, or is a pure tautology. According to the law of sufficient grounds, thinking is fundamentally continuous, and therefore the meaning of the concept is revealed through another concept, which is demonstrated in the epistemological principle of coherence. Therefore, "the thinker must solve an unthinkable problem: to build the phenomena of the world in a series, i.e. to explain them causally, as well as to understand the world as a whole, as simultaneity, as an aggregate, ie to destroy the idea of a series" [99, p. 520]. This dialectic of whole and particle is possible given the antinomic nature of pure reason. The space of freedom, the given of the possible, the imagination is the key to human power. M. Heidegger is convinced that transcendental cognition explores not the being itself, but the possibility of its prior understanding, and hence the existential composition of being. "The possibility of experience is equivalent to transcendence" [17, p.57] - so "possible" and is the dream path to freedom. The meaning of the antinomy of the mind is the possibility of making a choice, a practical attitude to the world. But the basis in practice is reflexive in advance, ie internalized is not actually potency and motivation. And so such freedom is closely related to destiny, or overdetermination, and is, in turn, a rational organization.

I. Kant calls Newton "the personification of the concept of science", but the whole pathos of his philosophy directed against the basic concept of his system of physics - "inertia". The mind prefers a different kind of orientation in the world, so Kant replaces the physical concept of "force" with the metaphysical concept of "freedom". And to substantiate this 
category of metaphysics, I. Kant uses all the tools of classical philosophy. The Kantian system is based on the principles and principles of rational cognition. In his analysis, Kant uses the transcendental method, but unlike the historical tradition, he considers it a guarantee of the integrity of things, not the ability to know, such as the connection between an object and its image, or a way of actualizing a thing (culturally determined). Culture is the horizon of eternity for the limited time of human existence. Human consciousness is receptive, operates with stable and stereotypical forms (or a priori). The schematic nature of this reception underlies the analyticalsynthetic construction, or activity of reason. This is the procedure of actualization of the modern phenomenological state, knowledge of existing existence and reflection of experience. To overcome this hermetic schematism, the subject uses the imagination, giving the frozen forms of experience the dynamics of goal-setting. Movement to the goal gives meaning to previous transformations, and allows dialectical synthesis of antinomies of pure reason. The mind is universal, because its symbolic nature gives unity to the diversity of the empirical world. This unity acquires meaning as goal-setting, freedom of choice and action, in retrospect of which the accidental acquires the status of natural. Thus, both at the level of empirical perception, and at the level of logical-rational distinctions, and at the level of the antinomy of freedom, measure and symbol are decisive.

Forms of perceptual experience do not arise by inert influence on the senses, but in the process of interaction between the subject and the world. Forms of cultural experience are formed as a fixation of the constant in change, stable and unchanging in numerous metamorphoses of life. Thus, phenomena are extensive in terms of perception, and consciousness evaluates them on the principle of anticipation, ie intensively, on the degree of severity and ability to influence. In this dialectic of freedom and necessity, creativity and causality, measure and symbol, the problem of genius as a 
universal individuality acquires special significance. It is in the concept of genius that the purpose of the existence of nature is revealed: the understanding of man as a subject of culture, capable of setting goals based on his own measure and ideas about values. Voluntary maxims do not refute the primacy of the rational in its ontological meaning. Thus, the subject has the ability to act freely, but acts purposefully, in the direction of affirming the ideals and values of culture. This postulate is a natural consequence of the Copernican turn, because human activity is not a goal but a means to an end. Accordingly, the doctrine of goal-setting is based on theoretical (awareness) and practical (duty) reason. Contradictions that arise from the collision of subject and object (both in the natural and in the social context) Kant calls antagonisms that cause the development of the human personality to the law. Even hostile communication is an explication of the need for the Other, or the sociality inherent in human nature. And the transition from direct response to reflection on actions and deeds based on notions of duty is the beginning of a culture, both personal and universal. Kant formulates the thesis-confession: "All culture and art that adorn humanity, the best social order - all the fruits of incommunicability, which by its very nature forces itself to discipline itself and thus by means of forced art to fully develop natural inclinations" [18, p.13]. Like nature, society is an antagonism of gravity and repulsion, the dynamics of the struggle between causality and freedom, nature and duty, needs and values.

By the same logic of interpretation of goal-setting, there is reason to consider the whole human history as "the ideal unity of the immanent goal" [14, p.13], and not just a sequence of modifications in space / time and causal connection of events. History becomes the horizon of the selfdetermination of the mind by voluntary means of realizing the precepts of duty (cultural value). In this projection, human subjectivity knows itself both as autonomy and as a component of social structure. Important in this 
aspect is the idea of the integrity of both the individual and society as a formative factor of integrity. After all, consciousness, both individual and social, is a product of communicative connections, which are possible under the condition of a universal code, the formation of which takes place on the basis of common ideals and values. And Kant unequivocally argues that freedom of thought and conscience is the result of the development of society and culture, not an attributive quality of human subjectivity. Indeed, communication is a systemic type of communication as coordination, harmony, stable interaction. The condition of this agreement is the commonality of ideals and values, ie the determinants that determine the course, means and purpose of activity. As M. Mamardashvili rightly remarked: "We are people when we are inside ontological tautologies, or tautologies of existence and understanding - contrary to the forces of nature and the flows of natural necessity" [19, p.272]. And in this positioning I. Kant saw a special pleasure, a separate manifestation of which is the phenomenon of culture.

In defining freedom as an axiom of society and culture, I. Fichte considers its ancestral essence, or sociality, to be fundamental. The act of constituting consciousness arises as an act of self-identification, the need for which is formed by society, a call from the Other in the communicative process. If the theoretical mind operates on the projections of things, the practical - determines the desire, freedom and interaction. Does the practical mind deal exclusively with ready-made images of objects? No, the mind is a unitary phenomenon, respectively, its praxis performs the function of determining integrity and determining meaning. Imitation of inertia is the cause of social evil, because its infliction is a lack of reason and education. Therefore, I. Fichte emphasizes the importance of educating the nation: individuals must be educated in people. The importance of education, or socialization and the formation of subjectivity is growing in view of activities 
to transform the world. In activity, human articulates his ideas about the laws of the universe, both natural and social. This cartography of time and space is, of course, determined by culture. It is logical that the establishment of such demarcation lines is regulated by the axiological basis of culture. What is their etymology: in historical and evolutionary development or in certain modifications of sacredness - the question is open. There is no doubt about the understanding of culture as an explication of activity on the basis of ethical and axiological norms that consolidate the unity of the human community. Therefore, Fichte expands the content of the Kantian concept of duty from the personal-individual dimension to the socio-state: the content of law and power is focused on the task of educating citizens, which corresponds to the natural logic of expediency.

The problem of natural substantiation of the unnatural, i.e. the search for ontological bases of the phenomenon of culture, is actualized by $F$. Schelling. An outstanding philosopher builds the argument of morality on the basis of the concepts of freedom, guilt, destiny. In his view, nature is not a finished product, or the result of becoming. The essence of nature is productivity, the ability to produce, or potentiality. Man has the opposite ability: not only to destroy or consume, but to complete, to give laconic forms of expression of being: in the image, concept, symbol. It is clear that culture is not only a product of activity, but also its cause. Therefore, even perceptiveness is a product of social interaction, culture.

This position is absolutized by G. Hegel. For him, to know being means to "remove" it in a concept that identifies thought and object. It is the logic of thinking of being that reveals its essence and purpose, the expediency of existence, which is an anthropomorphic dimension of knowledge of nature. In the dialectic of the abstract and the concrete, the essence and the existing beginning of being find their end in the forms of 
thinking. This is specifically the human, cultural way of life. The system of concepts, or the system of categorical thinking, forms the monumental structure of culture, or the prism of perception and evaluation of reality. In Hegel's terminology: the objective spirit as the human ancestral mind. And the understanding of world history as a progress of human freedom corresponds to the growth and improvement of forms of existence in culture. The movement of history is the transformation of cultural contexts, the improvement of the focus of perception and evaluation algorithms. Therefore, in Hegel's view, freedom implies renunciation of one's own self, of selfishness and of the risks associated with cultivating it. The tools of such renunciation are grounds to consider the aesthetic, as, for example, in the understanding of F. Schiller, when the aesthetic embodies the idea of harmony, contemplation and play, which makes possible the transition from sensory to moral. Other researchers, such as W. von Humboldt, cite language as an instrument of such a transition as the center of the cultural phenomenon, as a manifestation of the morality of the spirit, which seeks to express itself in sensory sounds and symbols. Or the position of F. Schleiermacher, according to which the mind penetrates into the logic of the existence of nature and influences its course in accordance with its own requests and needs. The author calls this ability the intelligentsia, the main feature of which is the activity of symbolization. The space of the symbol ensures the unity of humanity as a totality of many original personalities, reveals the space of explication of sociality and the formation of the architecture of culture. Thus, culture is a phenomenon that determines a certain pattern of perception and evaluation of reality, forms the procedures for defining and symbolizing the objects of the world. In other words, it produces a certain type of thinking, memory and imagination.

In the genesis of attempts to reflect on culture, one of the defining categories should be called sociality. We understand sociality as an 
attributive property of subjectivity, which consists in the demand of the Other for the explication of one's own essence. Sociality is that which compels or shifts a person to transcend from the ontic to the ontological level of perception and awareness. The formation of subjectivity involves mastering the logic and dynamics of culture. The personification of culture in the person of the subject is the process of forming the culture of personal thinking. Universal heritage (historical memory) in the communicative space of society is extrapolated to the individual consciousness, which, in turn, becomes the driving force of the cultural process.

\section{Conclusions.}

Thus, in the Western philosophical tradition, and in the German classics in particular, the idea of culture as a space of human immortality is postulated, involvement in culture means involvement in eternity. Culture sets the dimension in which prman finds his own essence and meaning of his existence, performs a kind of "analgesic" function before the pressure of the objective laws of nature. In other words, culture outlines the horizon of human existence, a world suitable for human life. The general content of the human strategy of world development is symbolization and formalization. Thus, the symbol-sign is the instance that transforms potency (essence) into actuality (reality), secret into phenomenon, and internal into external. The course of thought is roughly as follows: being exists as discreteness, but is phenomenologically perceived as length. To perceive the integrity and completeness of being throughout the experience of the world requires a certain interest of the subject. At the heart of this interest is the need that drives a person's attention. And culture as a space of Spirit, meaning and values shapes these needs, or requests.

\section{References:}


1. James, D. (2016) Enlightenment and the Unconditional Good: From Fichte to the Frankfurt School. International Journal of Philosophical $\begin{array}{lllll}\text { Studies } \quad \text { Volume } 24, & \text { Issue } & 1 . & P . & \text { 26-44. }\end{array}$ https://doi.org/10.1080/09672559.2015.1107614

2. Piirimäe, E. (2015 Schmidt A. Introduction: Between Morality and Anthropology-Sociability in Enlightenment Thought. Volume 41, Issue 5: Sociability in Enlightenment Thought. P. 571-588. https://doi.org/10.1080/01916599.2014.987538

3. Baghai, F. (2020) The Disciplinary Conception of Enlightenment in Kant's Critical Philosophy. Critical Horizons. A Journal of Philosophy and Social Theory. Volume 21, Issue 2. P. 130-152. https://doi.org/10.1080/14409917.2020.1759282

4. Cain, A. (2020) The Metaphysical Spectator and the Sphere of Social Life in Kant's Political Writings. Critical Horizons. A Journal of Philosophy and Social Theory. Volume 21, Issue 2. P. 153-166. https://doi.org/10.1080/14409917.2020.1759283

5. Laitinen, A., Mayr, E., Sandis, C. (2018) Kant and Hegel on purposive action. Philosophical Explorations. An International Journal for the Philosophy of Mind and Action. Volume 21, Issue 1: Philosophy of Action from Suarez to Anscombe. P. https://doi.org/10.1080/13869795.2017.1421693

6. Schafer, K. (2019) Kant: constitutivism as capacities-first philosophy. Philosophical Explorations. An International Journal for the Philosophy of Mind and Action. Volume 22, Issue 2: Varieties of Constitutivism. Pages 177-193.https://doi.org/10.1080/13869795.2019.1599049

7. Ware, O. (2019) Fichte's method of moral justification. British Journal for the History of Philosophy Volume 27, Issue 6. P. 11731193.https://doi.org/10.1080/09608788.2018.1544543 
8. Moggach, D. (1996) Fichte's theories of intersubjectivity. The European Legacy. Toward New Paradigms. Volume 1, Issue 6. P. 19341948. https://doi.org/10.1080/10848779608579647

9. Lambier, J. (2007) The organismic state against itself: Schelling, Hegel and the life of right. European Romantic Review Volume 19, 2008 Issue 2: BARS/NASSR. CONFERENCE: EMANCIPATION, LIBERATION, FREEDOM. P. 131-137. https://doi.org/10.1080/10509580802030359

10. Redding, P. (2019) Hegel, modal logic, and the social nature of mind. Inquiry. An Interdisciplinary Journal of Philosophy. Volume 62, Issue 5: Non-Reductivism and the Metaphilosophy of Mind. P. 586-606. https://doi.org/10.1080/0020174X.2018.1484007

11. Testa, I. (2009) Second Nature and Recognition: Hegel and the Social Space. Critical Horizons. A Journal of Philosophy and Social Theory. Volume 10, - Issue 3. P. 341-370. https://doi.org/10.1558/crit.v10i3.341

12. Бицилли, П. М. (1995) Элементы средневековой культуры. СПб.: Мифрил. 244.

13. Библер, В. С. (1991) От наукоучения - к логике культуры. (Два философских введения в двадцать первый век). Москва: Издательство политической литературы. 414.

14. Кант, И. (1966) Сочинения в шести томах. (Философрское наследие. Акад. наук СССР. Ин-т философии) / Под общ. ред. В. Ф. Асмуса, А. В. Гулыги, Т. И. Ойзермана. Москва, изд-во «Мысль». Т. 6. 742.

15. Мамардашвили, М. (2002) Кантианские вариации. Москва: «Аграфр». 320.

16. Кант, И. (1965) Сочинения в шести томах. (Философрское наследие. Акад. наук СССР. Ин-т философии) / Под общ. ред. В. Ф. Асмуса. А. В. Гулыги, Т. И. Ойзермана, Москва, изд-во «Мысль». Т. 4. 4. 2. 478. 
17. Хайдеггер, М. (1997) Кант и проблема метафизики. Москва: Русское френоменологическое общество. 176.

18. Кант, И. (2006) Сочинения на немецком и русском языках. В 4 томах. Том 2: Критика чистого разума. В 2 частях. Часть 1. Москва: Наука. 1082.

19. Мамардашвили, М. К. (2011) Сознание и цивилизация. СПб.: Азбука, Азбука-Аттикус. 272.

\section{References:}

1. James, (2016) D. Enlightenment and the Unconditional Good: From Fichte to the Frankfurt School. International Journal of Philosophical $\begin{array}{llllll}\text { Studies } & \text { Volume } & 24 . & \text { Issue } & 1 . & \text { P. }\end{array}$ https://doi.org/10.1080/09672559.2015.1107614

2. Piirimäe, E. (2015) Schmidt A. Introduction: Between Morality and Anthropology-Sociability in Enlightenment Thought. Volume 41. Issue 5: Sociability in Enlightenment Thought. P. 571-588. https://doi.org/10.1080/01916599.2014.987538

3. Baghai, F. (2020) The Disciplinary Conception of Enlightenment in Kant's Critical Philosophy. Critical Horizons. A Journal of Philosophy and Social Theory. Volume 21. Issue 2. P. 130-152. https://doi.org/10.1080/14409917.2020.1759282

4. Cain, A. (2020) The Metaphysical Spectator and the Sphere of Social Life in Kant's Political Writings. Critical Horizons. A Journal of Philosophy and Social Theory. Volume 21. Issue 2. P. 153-166/ https://doi.org/10.1080/14409917.2020.1759283

5. Laitinen, A., Mayr, E., Sandis, C. (2018) Kant and Hegel on purposive action. Philosophical Explorations. An International Journal for the Philosophy of Mind and Action. Volume 21. Issue 1: Philosophy of Action from Suarez to Anscombe. P. $90-107$. https://doi.org/10.1080/13869795.2017.1421693 
6. Schafer, K. (2019) Kant: constitutivism as capacities-first philosophy. Philosophical Explorations. An International Journal for the Philosophy of Mind and Action. Volume 22. Issue 2: Varieties of Constitutivism. Pages 177-193.https://doi.org/10.1080/13869795.2019.1599049

7. Ware, O. (2019) Fichte's method of moral justification. British Journal for the History of Philosophy Volume 27. Issue 6. P. 11731193.https://doi.org/10.1080/09608788.2018.1544543

8. Moggach, D. (1996) Fichte's theories of intersubjectivity. The European Legacy. Toward New Paradigms. Volume 1. Issue 6. P. 19341948. https://doi.org/10.1080/10848779608579647

9. Lambier, J. (2008) The organismic state against itself: Schelling, Hegel and the life of right. European Romantic Review Volume 19. - Issue 2: BARS/NASSR 2007 CONFERENCE: EMANCIPATION, LIBERATION, FREEDOM. P. 131-137. https://doi.org/10.1080/10509580802030359 (eng) 10. Redding, P. (2019) Hegel, modal logic, and the social nature of mind. Inquiry. An Interdisciplinary Journal of Philosophy. Volume 62. Issue 5: Non-Reductivism and the Metaphilosophy of Mind. P. 586-606. https://doi.org/10.1080/0020174X.2018.1484007

11. Testa, I. (2009) Second Nature and Recognition: Hegel and the Social Space. Critical Horizons. A Journal of Philosophy and Social Theory. Volume 10. Issue 3. P. 341-370. https://doi.org/10.1558/crit.v10i3.341

12. Bitsilli, P. M. (1995) Elementy srednevekovoy kul'tury. SPb.: Mifril, 1995. 244. (In Russian)

13. Bibler, V. S. (1991) Ot naukoucheniya - k logike kul'tury. (Dva filosofskikh vvedeniya v dvadtsat' pervyy vek). Moskva: Izdatel'stvo politicheskoy literatury. 414. (In Russian)

14. Kant, I. (1966) Sochineniya v shesti tomakh. (Filosofskoye naslediye. Akad. nauk SSSR. In-t filosofii) / Pod obshch. red. V. F. Asmusa, A. V. Gulygi, T. I. Oyzermana. Moskva, izd-vo «Mysl'». T. 6. 742. (In Russian) 
15. Mamardashvili, M. (2002) Kantianskiye variatsii. Moskva: «Agraf». 320 p. (In Russian)

16. Kant, I. (1965) Sochineniya v shesti tomakh. (Filosofskoye naslediye. Akad. nauk SSSR. In-t filosofii) / Pod obshch. red. V. F. Asmusa. A. V. Gulygi, T. I. Oyzermana, Moskva, izd-vo «Mysl'». T. 4. CH. 2. 478 p. ((In Russian)

17. Khaydegger, M. (1997) Kant i problema metafiziki. Moskva: Russkoye fenomenologicheskoye obshchestvo, 1997. 176 p. (In Russian)

18. Kant, I. (2006) Sochineniya na nemetskom i russkom yazykakh. V 4 tomakh. Tom 2: Kritika chistogo razuma. V 2 chastyakh. Chast' 1. Moskva: Nauka. 1082 p. (In Russian)

19. Mamardashvili, M. K. (2011) Soznaniye i tsivilizatsiya. SPb.: Azbuka, Azbuka-Attikus. 272 p. (In Russian)

Citation: O. Yatsenko (2021). THE PROBLEM OF SOCIALITY IN GERMAN CLASSICAL PHILOSOPHY: BETWEEN FREEDOM AND NECESSITY. New York. TK Meganom LLC. Innovative Solutions in Modern Science. 2(46). doi: 10.26886/2414-634X.2(46)2021.5

Copyright: O. Yatsenko ( 0.2021 . This is an openaccess article distributed under the terms of the Creative Commons Attribution License (CC BY). The use, distribution or reproduction in other forums is permitted, provided the original author(s) or licensor are credited and that the original publication in this journal is cited, in accordance with accepted academic practice. No use, distribution or reproduction is permitted which does not comply with these terms. 